\title{
Stille i pressen?
}

\author{
Ved A lexandra Beverfjord og Toril G rande
}

\section{Selumord eller selumordsforsøk skal som hovedregel ikke omtales. Dette har stått nedfelt i pressens Vaer Varsom-plakat siden 1936, og som hovedregel gjelder det fremdeles. Likevel blir det for enkelt å avvise et alvorlig samfunnsproblem med å skyve problematikken under teppet. Det er medias plikt å bringe slike tema til overflaten og belyse dem for at samfunnet skal kunne sette inn mottiltak. Det kan vaere vanskelig å snakke om selvmord, men slutter vi å snakke om det, vil fordommene $ø k$. Responsen fra leserne på reportasjer om selumord og sorg viser at temaet engasjerer og opprører, men gir også gjenkjennelse og trøst.}

Selvmord er et journalistisk minefelt. Det er et tungt og vanskelig område, som for journalisten innbefatter sterke personlige møter med mennesker i en fortvilet situasjon, stor tillit og et tungt ansvar. A eksponere etterlatte i desperat søken etter en forklaring, eller intervjue personer som enten er lykkelige eller lei seg etter et selvmordsforsøk, krever at journalisten utviser diskresjon og forsiktighet, både av hensyn til de berørte parter og til leserne, som kan ha ulike reaksjoner på det som blir presentert.

A rtikkel forfatterne er journalister i Dagbladets M agasinet, og vi vil gjerne ta utgangspunkt i vårt eget arbeid med en artikkel vi samarbeidet om i fjor (på trykk 18. mai 2002). U nder tittelen «Livet etterpå» tok vi utgangspunkt $i$ at det hvert år er rundt 500 som tar sitt eget liv i N orge. Tilbake sitter venner og familie med følelser som sorg, skyld og fortvilelse. G jennom ni sider fikk $M$ agasinets lesere møte flere etterlatte etter selvmord. U ndertegnede begynte på arbeidet med artikkelen allerede i februar 2002, etter at LEVE, Landsforeningen for etterlatte ved selvmord, hadde tatt kontakt med oss. Som journalister har vi ikke de samme forutsetningene som fagfolk til å møte mennesker i sorg, men vår erfaring er at journalisten kan ha en viktig rolle som lytter, formidler og medmenneske.

Vi jobbet tett opp mot LEVE og også fagfolk fra begynnelse til slutt. For oss var det viktig at de etterlatte som stilte opp i artikkelen, skulle føle seg komfortable med intervjusituasjonen, det endelige resultatet på trykk og oppfølgingen etterpå. Derfor fikk alle involverte en helt annen innflytelse over artikkelens innhold og presentasjon enn det vi van- ligvis tillater at intervjuobjekter får. I tillegg ble saken fortløpende drøftet med våre reportasjeledere. Det ble mange runder fram og tilbake, og vi tok oss god tid i denne prosessen. Tilbakemeldingene vi fikk fra de involverte, var at de satte pris på empatien og videreformidlingen de ble møtt med. Likevel: Det å stå frem i media kan utvilsomt også bli en belastning, og denne risikoen må intervjuobjektene på forhånd gjøres oppmerksomme på. N oen finner en lettelse i å få presentert sin historie offentlig på en måte de føler seg komfortable med. Det har hjulpet dem med å sette ord på følelser og reaksjoner, og kanskje åpnet opp for en kommunikasjon. Som journalister opplever vi stadig at folk som har opplevd noe dramatisk og har behov for å snakke, bruker oss som en menneskelig ventil. For enkelte har et presseoppslag vært starten på et engasjert hjelpearbeid for andre som kommer i samme situasjon, uten at vi dermed kan anbefale medieoppslag som terapi.

Leserreaksjonene strømmet på i tiden etter at artikkelen hadde stått på trykk. G jennom et utall telefoner, brev og e-post-meldinger fortalte leserne oss at behovet for mer åpenhet om temaet var stort. Vi opplevde det som et sug etter mer informasjon. Enkelte av de som kontaktet oss, var selv etterlatte etter selvmord, andre fortalte at de selv hadde vært i en slik situasjon der de hadde forsøkt å ta sitt eget liv. Vi var opptatte av å møte disse reaksjonene med varsomhet. $\mathrm{N}$ oen av henvendelsene kom på trykk som leserbrev, hvis forfatteren ønsket det, langt flere deltok i en egen diskusjonsbase på nettet. Påfallende mange henvendte seg direkte til oss som hadde signert artikkelen. Vi bestrebet oss på å gi samtlige et personlig svar, der vi uttrykte forsiktig medfølelse og ellers hen viste til adresser og tel efoner til hjelpeapparatet, slik det forøvrig ble gjort også i artikkelen i $M$ agasinet.

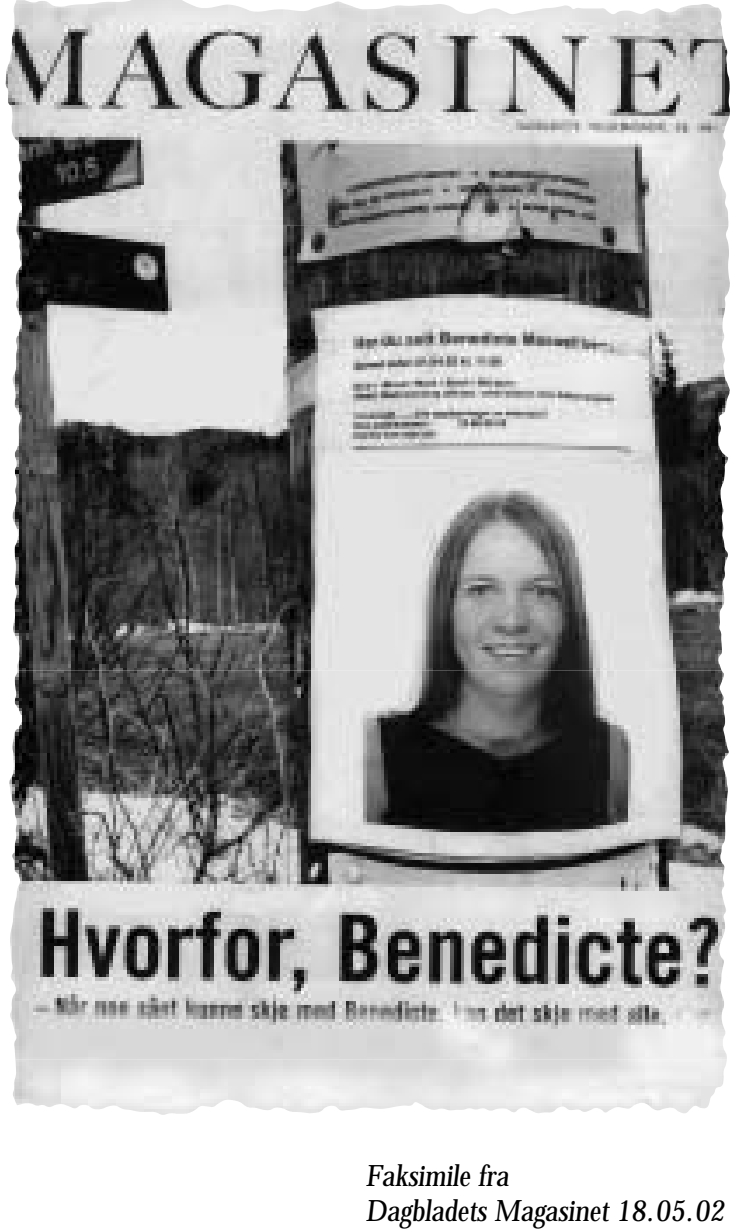


H vis vi skal se på selvmord i et pressehistorisk perspektiv, ligger som nevnt det etiske grunnlaget i V ær Varsom-plakatens pkt. 4.9: "Selvmord eller selvmordsforsøk skal som hovedregel ikke omtales". Dette er en bestemmelse norsk presse har etterlevd temmelig lojalt siden den første plakaten kom i 1936. Et viktig unntak skjedde i 1954 da Dagbladet brakte et stort oppslag på første side om skøytehelten O scar M athiesen navngitt og med heltebilde - som hadde skutt seg selv. I ettertid ville man kanskje si at det var et drama med offentlig kjente personer og derfor av offentlig interesse. I O slo-pressen i 1950åra, da kriminaljournalistikken var temmelig hardkokt, faktisk mye mer hardkokt enn i dag, førte ikke oppslaget til innklaging til Pressens Faglige U tvalg (PFU ), eller Det Faglig Råd, som det den gang het. Internasjonalt sett er det ganske nylig at W HO har utarbeidet retningslinjer for hvordan presse og etermedia bør behandle nyheter om selvmord, og der advares det særlig mot detaljerte beskrivelser av anvendt metode (se s. 11 - 13.) Det skjedde først i år 2000.

Det er altså helt unntaksvis at selvmord er blitt konket omtalt i den løpende nyhetsdekningen. N oen vil huske en skolesjef på $\mathrm{H}$ adeland, en børsdirektør og nå nylig - en tidligere hel seminister, som ble drevet til selvmord på grunn av offentlig framsatte svindelanklager. M en i de fleste forsvinningssaker er forklaringen gjerne blitt pakket inn i runde formuleringer som "en personlig tragedie" eller "det lå ikke noe kriminelt bak". Ser vi på andre lands presseskikk, har norsk og til dels også svensk presse generelt vært mer tilbakeholdende med å omtale selvmord enn medier $\mathrm{i}$ andre land. Det finnes trolig sosiokulturelle forklaringer på det. $M$ an kan anta at det henger sammen med at sel vmord var ytterst skambelagt og strengt fordømt i folketro og religion. I gamle dager kunne ikke den som begikk selvmord, bli gravlagt i vigslet jord. Det er først i de seinere åra at selvmord av og til avspeilesi dødsannonsene, f. eks. slik: "valgte å forlate oss" eller "klarte ikke mer". Slike formuleringer avspeiler at avtabuiseringen er i gang ute blant folk flest.

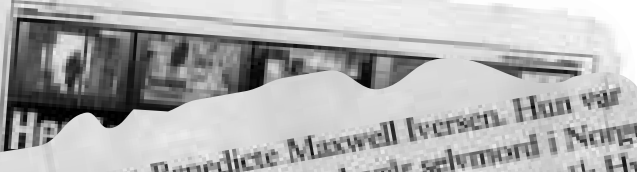

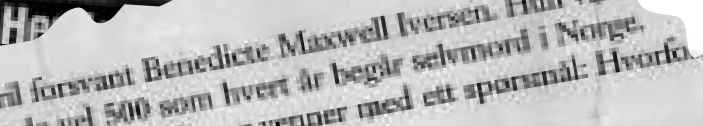

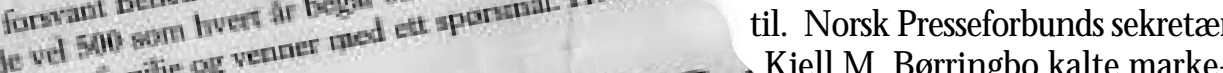

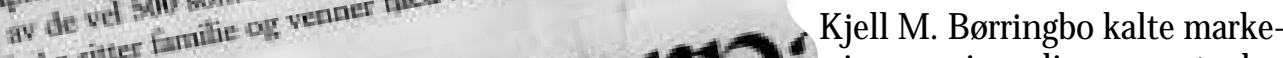

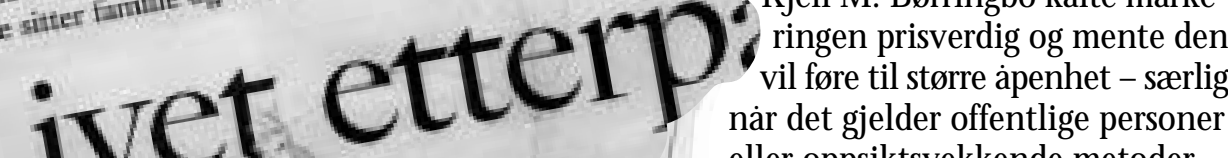
wint

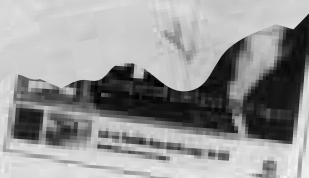
(jfr. dødshoppene fra Preikestolen). Siden 1996 har PFU behandlet sju klager om selvmord og gitt klagerne medhold i fem av sakene. En ny klagesak står for trappene: Det dreier seg ikke om en pårørende, men en allminnelig leser, som klager over at Dagbladet i november 2002 brakte en serie om reportasje om selvmord på nyhetsplass. «Dagbladet handlet mot bedre vitende», anførte klageren og slo fast som faktum at omtale av selvmord har en smitteeffekt. Den mulige smitteeffekten skal vi i pressen være oppmerksomme på og ta med i vurderingen når vi tar opp et slikt tema, men selvmord kan ikke tiesihjel. I N orge dør dobbelt så mange av selvmord som i bilulykker, og atskillig flere forsøker hvert år å ta sitt eget liv. Det er en oppgave for media å fortelle om selvmord som en utfordring for samfunnet. Etter å ha lest gjennom leserreaksjonene, der svært mange etterlatte etter selvmord uttrykte tydelig lettel se over å kunne lese om andre som sto frem med sin historie, føler vi at dette representerer nyttig informasjon som har en viktig plass i media. Størst inntrykk gjør nok skjebner der de som intervjues, stiller åpent opp med navn. Det gir historien autentisitet og reduserer tabufølelsen i forhold til anonymiserte reportasjer med uklare bilder og fiktive navn. Vi håper at artikler som «Livet etterpå» kan være med på å flytte tabuene. ryktestorm som fort ville bre seg over by og land, ville være mer skadelig enn kunngjøring gjennom pressen. A t statsministerens ønske i så stor grad ble lojalt respektert, forteller sitt både om en "snill og lydig" presse og om landsmoderens posisjon.

Et tydelig skifte når det gjelder omtale av selvmord, kom våren 2002 da "tanta i A kersgata", A ften posten - etter mange ukers offentlig etterlysning etter en ung kvinne, Benedicte - konstaterte i en tospaltet tittel på første side: "Benedicte tok sitt eget liv". Det var et bevisst regelbrudd fra avisledel sens si de, fordi saken hadde fått så stor oppmerksomhet, noe

A lexandra B everfjord og Toril G rande er journalister i Dagbladets M agasinet.

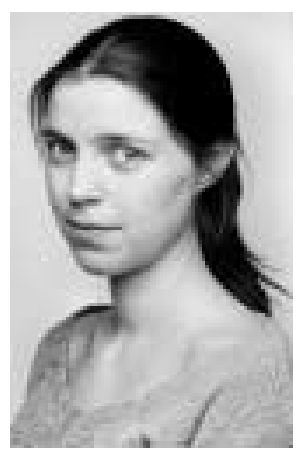

A lexandra Beverfjord

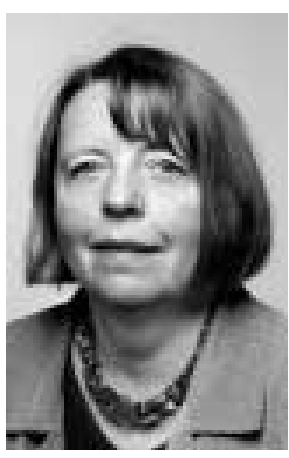

Toril G rande

Stille i pressen? 